УДК 94(569.4)"70/638"

DOI 10.18413/2687-0967-2020-47-1-54-66

\title{
САВВА ОСВЯЩЕННЫЙ (439-532 ГГ.) И МОНАСТЫРИ ИУДЕЙСКОЙ ПУСТЫНИ В ИЗОБРАЖЕНИИ КИРИЛЛА СКИФОПОЛЬСКОГО
}

\author{
ST. SABBAS THE SANCTIFIED (439-532) AND MONASTERIES \\ OF THE JEWISH DESERT IN THE DEPICTION OF CYRIL OF SKYTHOPOLIS
}

\author{
Ю.В. Шелудченко \\ Yu.V. Sheludchenko
}

\begin{abstract}
Белгородский государственный национальный исследовательский университет, Россия, 308015 г. Белгород, ул. Победы, 85,

Belgorod National Research University, 85, Pobeda st., Belgorod, 308015, Russia

E-mail: 240673@bsu.edu.ru
\end{abstract}

\begin{abstract}
Аннотация
Тема данной работы посвящена анализу жизни и религиозной деятельности св. Саввы знаменитого подвижника и святого V - начала VI вв., прославившегося в Иудейской пустыне Палестины, - на материале его «Жития», написанного его учеником и младшим современником Кириллом Скифопольским. На основе данных «Жития св. Саввы» исследуются основные вехи жизни святого и его деятельность, историко-религиозная ситуация в ранневизантийской Палестине второй половины V - первой половины VI вв. и роль св. Саввы в происходящих событиях. В результате можно сделать вывод, что св. Савва активно участвовал в исторических событиях вышеуказанного периода и был очень значимой фигурой в регионе. Его «Житие» отличается высокой достоверностью и является важным историческим источником.
\end{abstract}

\begin{abstract}
The theme of this work is devoted to the analysis of life and religious activity of St. Saba - the famous ascetic and saint in the V - beginning of the VI centuries AD, famous in the Palestinian desert - on the material of his «Life», written by his student and younger contemporary Cyril Scythopolitanus. Based on the data of the «Life of St. Saba» this article explores the main milestones of the saint's life and his activities, the historical and religious background in early Byzantine Palestine in the second half of the fifth and first half of the sixth century, and the role of st. Saba in ongoing events. As a result, we can conclude that st. Saba actively participated in the historical events of the above period and was a very significant figure in the region. His «Life» is highly reliable and it is an important historical source. It gives complex analysis about religious situation in Late Antique Palestine, monasticism there, struggle between religious movements, Jerusalem patriarchy.
\end{abstract}

Ключевые слова: св. Савва, Кирилл Скифопольский, «Житие св. Саввы», ранневизантийская агиография, ранневизантийская Палестина.

Keywords: St. Sava, Cyril Scythopolitanus, «Life of St. Saba», early-Byzantine hagiography, earlyByzantine Palestine.

В центре внимания «Жития св. Саввы» Кирилла Скифопольского (524-558) [Dölger, Schwartz, 1940] находится фигура самого святого. Кирилл Скифопольский являлся учеником св. Саввы [Ткачев, 2014], которого сам святой так нарек, когда агиограф был еще маленьким мальчиком (Cyr. V. Sab. 75) [Schwartz, 1939; Binns, 1991; Помяловский, 1885]. Поэтому Кирилл стремится наиболее точно, достоверно и подробно передать жизнь св. Саввы, выполняя ученический долг перед своим наставником. 
В основе повествования - устные свидетельства монахов, очевидцев событий, непосредственно общавшихся с самим святым, в том числе родственников и наставников самого Кирилла. Также были использованы его собственные личные наблюдения и воспоминания [Elliott-Binns, 1989, p. 62]. Это делает данное произведение, которое является наиболее обширным из всех «Житий» Кирилла, аутентичным и весьма важным историческим источником по религиозной жизни в Палестине во 2-й пол. V - 1-й пол. VI вв. Несмотря на то, что «Житие св. Саввы» соответствует жанрам и канонам житийной литературы [Маторина, 2011], оно весьма исторично и содержит много сведений о религиозной истории региона. Можно сказать, что данное «Житие» представляет собой смесь жанров агиографии и церковной истории.

Начало сбора материала для написания этой работы относится, как указывает автор, ко времени не ранее чем 80 лет спустя после смерти св. Евфимия (Cyr. V. Sab. 1), который, как известно из его собственного «Жития», умер в 473 г. [Шелудченко, 2019]. «Житие св. Евфимия» Кирилл написал через два года после переселения в Новую лавру в 555 г. [Elliott-Binns, 1989, p. 50], и только затем приступил к «Житию св. Саввы» (Cyr. V. Euth. 83) [Schwartz, 1939; Binns, 1991; Помяловский, 1898], то есть время работы можно датировать примерно 557/58 годом. Кирилл доводит повествование до 553 г., завершая его V Вселенским собором и переселением монахов-халкидонитов в Новую лавру взамен выгнанных оригенистов, современником и участником каковых событий он непосредственно являлся (Cyr. V. Sab. 90).

«Жизнь св. Саввы» помещена в строгие хронологические рамки, для каждого события из жизни святого Кирилл Скифопольский дает несколько хронологических привязок: по времени правления того или иного императора, консульствам, индиктам, времени правления патриархов Иерусалимских, указывая точный возраст святого, так что можно датировать все события из жизни святого подвижника достаточно точно. Интересно, что Кирилл Скифопольский придерживался наиболее авторитетной в то время александрийской эры [Кузенков, 2014, с. 251-252], так что все точные датировки по годам надо увеличивать на 8 лет в соответствии с современной эрой.

Чтобы понять вехи жизни и деятельности святого, следует уточнить все даты, что можно сделать по более-менее точным «Хроникам» Марцеллина Комита (VI в.) [Болгов, 2010] и «Пасхальной» (1 пол. VII в.) [Whitby, Whitby, 1989].

Дата рождения св. Саввы - год 17 консульства Феодосия, то есть 439 год (Cyr. V. Sab. 3; Marc. Com. a. 439; Pasch. Chr. a. 439). Он родился в селении Муталаски близ Кесарии Каппадокийской в Малой Азии. Его родители были христиане: Иоанн и София. Его отец был военным командиром, и когда Савве было 5 лет, отца перевели в Александрию в составе отряда исавров, это произошло в 444 г., сына оставили в селе на попечении родственников. В 8 лет Савву отправили в монастырь Флавиана, расположенный в 20 стадиях от родного села, до совершеннолетия, где мальчик провел 10 лет до 18-летия, то есть с 447 до 457 гг. (Cyr. V. Sab. 4-6, 77). В 18 лет (в 457 г.) юноша прибыл в Иерусалим, в конце правления Иерусалимского патриарха Ювеналия, которому оставалось жить всего два года [Honigmann, 1950].

В Иерусалиме Савва сначала остановился в лавре св. Пассариона, под управлением игумена Эльпидия, где его принял каппадокийский земляк, затем отправился в лавру св. Евфимия. Святой отказался принять Савву в лавру, так как он был слишком юн, и отослал в лежащую по соседству киновию своего друга и соратника бл. Феоктиста (Cyr. V. Euth. 47; V. Sab. 7-10). Там юноша провел 9 лет, а на десятом году скончался Феоктист, в 4 индикт, т. е., в 466 г. (Cyr. V. Sab. 10; Marc. Com. a. 466; Pasch. Chr. a. 466). Преемник Феоктиста сарацин Марис умер через два года - в 468 г., тогда Савве исполнилось 30 лет. Его преемником стал Лонгин, который позволил молодому подвижнику жить в отшельничестве в пещере, приходя в монастырь только на воскресные службы, - так святой прожил 5 лет до 473 г. С этого времени также св. Евфимий стал брать Савву с собой поститься на 40 дней в пустыню (Cyr. V. Euth. 52-55; V. Sab. 10-11), от праздника Богоявления до праздника Ваий (ветвей - Входя Господня в Иерусалим) [Шелудченко, 2019]. 
Когда св. Савве шел 35-й год, то есть в 473 г., умер св. Евфимий. Кирилл в различных житиях упоминает о смерти святого, давая несколько хронологических ориентиров: это время 16-го года правления и 5-го консульства императора Льва и 15-й год патриаршества Анастасия (459-478) (Cyr. V. Euth. 55-59; V. Sab. 11; V. Geras. 5; V. Cyriac. 5; Marc. Com. a. 473; Pasch. Chr. a. 473) [Schwartz, 1939; Binns, 1991; Помяловский, 1895a; Помяловский, 1895b], вступившего на престол после смерти патриарха Ювеналия в 459 г. (Cyr. V. Euth. 34, 49). Несмотря на то что Лонгин продолжал быть игуменом монастыря еще 12 лет после смерти Евфимия, до 485 г. (Cyr. V. Euth. 67-70), Савва почти сразу уходит из Нижнего монастыря, так как «в киновии образ жизни переменился, поелику отцы обители скончались».

Он начинает жить отшельником в пустыне, проведя так 4 года (Cyr. V. Sab. 12-15). B пустыне он познакомился с Анфом, учеником бл. Феодосия, пресвитера Седалищной церкви. Вероятно, с этого времени берет начало крепкая дружба Саввы и Феодосия (Cyr. V. Sab. 65), которая по своей сущности весьма походит на дружбу св. Евфимия с Феоктистом в плане монастырской деятельности [Шелудченко, 2019]: Савва впоследствии отсылал всех приходящих, которые не были готовы к жизни в лавре, в киновию Феодосия, которая находилась в 35 стадиях к западу от Великой лавры (Cyr. V. Sab. 29). Св. Феодосию Киновиарху посвящено отдельное житие [Schwartz, 1939; Binns, 1991; Помяловский, 1899].

В 477 г. 38-летний Савва набрел на гору, где стояла башня, некогда выстроенная императрицей Евдокией, для общения с его учителем св. Евфимием (Cyr. V. Euth. 44-45; V. Sab. 15). Савва поселился в пещере неподалеку, к востоку от ручья, протекавшего с южной стороны горы. Это случилось в 478 г., в год смерти патриарха Иерусалимского Анастасия, когда император Зенон вернулся на престол, свергнув узурпатора Василиска (Pasch. Chr. a. 478). Преемником Анастасия стал Мартирий (478-486), происходивший из Каппадокии и бывший учеником св. Евфимия, также постившийся с ним в пустыне [Шелудченко, 2019]. Патриарх Мартирий умер через 8 лет (Cyr. V. Sab. 15, 19).

Прожив в пещере 5 лет с 483 г., св. Савва стал принимать учеников и основал лавру, впоследствии получившую название Великая лавра. Первыми его учениками стали Иаков - в будущем основатель лавры с башнями при Иордане, Фирмин - основатель лавры в местности Махмаса, Севериан - основатель лавры Перикарпарвариха, Юлиан Кирт (Горбатый) - основатель лавры Неслкерава у Иордана, и другие. В Великой лавре была построена церковь у ручья, а вскоре освящена пещера, где святому явился огненный столб и которая своими очертаниями напоминала церковь. Савва поселился отдельно от всех в башне над пещерой-церковью, из которой туда вел скрытый ход. Число монахов Великой лавры увеличилось до 150 человек, в лавре был заведен рабочий скот и хозяйство, также посреди обители был обнаружен источник питьевой воды (по молитвам святого) (Cyr. V. Sab. 16-18). Лавре благоволил патриарх Мартирий, который знал Савву еще по совместным постам в пустыне при Евфимии (Cyr. V. Euth. 54-55).

После смерти Мартирия в 486 г., когда Савве шел 48-й год, на патриарший престол Иерусалима был поставлен патриарх Саллюстий (486-494). Тогда же у Саввы начались конфликты с монахами, которые обвиняли его в том, что Савва не был священником и не может служить в церкви, так что службы были нерегулярны, а зависели от приходящих пресвитеров. Через 5 лет, когда Савве шел 53-й год, в 14 индикт, когда на престол взошел Анастасий, то есть в 491 г. (Marc. Com. a. 491; Pasch. Chr. a. 491), монахи не выдержали и послали в Иерусалим делегацию, прося заменить игумена. Тогда Саллюстий рукоположил святого в пресвитеры и лично освятил церковь-пещеру в Великой лавре вместе с Кириком, крестохранителем храма св. Воскресения и сторонником св. Саввы, также доставив туда много мощей и реликвий (Cyr. V. Sab. 19).

В это время в жизни св. Саввы произошло несколько значимых событий. Он в течение каждого года удалялся в Иудейскую пустыню поститься от Богоявления до праздника Ваий, подражая св. Евфимию. В 491 г., будучи близ Мертвого моря в местечке Зоора, св. Савва провалился в яму с гейзером и сильно опалил себе лицо, после чего у него перестала расти борода на лице. Выбрался он буквально чудом, как свидетельствует Кирилл 
Скифопольский. В этот же год он вместе с учеником Агапитом совершил паломничество по всем святым местам Палестины, пройдя вдоль Иордана до Панеады (у горы Хермон на севере) и встретив по пути святого отшельника (Cyr. V. Sab. 22-24).

Также в Великой лавре в это время сформировалась армянская община: там поселился 38-летний армянский епископ св. Иоанн Молчальник и армяне Иеремия с учениками Петром и Павлом, а затем и другие. Павел впоследствии стал одним из информаторов Кирилла, как и Иоанн Молчальник (Cyr. V. Sab. 22-25). Св. Иоанну Молчальнику автор посвятил отдельное житие [Schwartz, 1939; Binns, 1991; Помяловский, 1893], где сообщает, что он родился в 454 г., в 4-й год правления императора Маркиана (450-457) и 7 индикт в Армении (Cyr. V. Ioan. 1; Marc. Com. a. 454; Pasch. Chr. a. 454).

В том же 491 г. умер отец св. Саввы Иоанн-Конон в Александрии, а мать прибыла в Палестину, будучи в глубокой старости, и постриглась в монахини по убеждению сына, но вскоре скончалась. Она привезла большие средства сыну, которые дали ему возможность расширить лавру: были построены странноприимные дома в лавре, а также Савва приобрел странноприимный дом с садами и водой в Иерихоне (Cyr. V. Sab. 25-26).

На следующий год, в 15 индикт (492 г.) (Marc. Com. a. 492; Pasch. Chr. a. 492), 54-летний Савва прибыл на холм Кастеллий, в 20 стадиях к северо-востоку от Великой лавры, откуда изгнал бесов, расчистил место и основал там киновию. Настоятелем был назначен его ученик Павел, а его помощником - Феодосий из Мелитены, впоследствии ставший и его преемником (Cyr. V. Sab. 27). В конце VI в. настоятелем киновии был Агафоник, рассказывавший Иоанну Мосху (550-620) [Trapp, 1992] различные истории о монахах и истории монастыря (Mosch. Prat. spir. 167) [Хитров, 1915].

Провизией монахов на момент работы на Кастеллийском холме снабжал настоятель Вифлеемского монастыря Маркиан, умерший в этом же году, через 4 месяца (Cyr. V. Sab. 27). Изначально Маркиан был монофизитом и учеником Эльпидия, ученика св. Пассариаона - после обращения Эльпидия в халкидонское вероисповедание св. Евфимием он примкнул к другому монофизиту Геронтию в 450-е годы, основав свою киновию, но в 485 г. соединился с халкидонитами (Cyr. V. Euth. 40, 46, 71) [Шелудченко, 2019]. В 492 г. незадолго до смерти патриарх Саллюстий его также назначил архимандритом монастыря св. Пассариона. После его смерти тогда же была произведена монашеская реформа - все монахи собрались в Иерусалиме, и патриарх назначил главой всех киновий св. Феодосия Киновиарха, а главой всех лавр и отшельников - св. Савву (Cyr. V. Sab. 30, 33). Заместителем Феодосия был авва Павел, игумен обители аввы Мартирия, вероятно, обители покойного патриарха, который основал ее в 15 стадиях к западу от лавры св. Евфимия еще при жизни святого (Cyr. V. Euth. 48).

Через 8 лет правления, во 2-й индикт (494 г.) (Marc. Com. a. 494; Pasch. Chr. a. 494), патриарх Саллюстий скончался, а его преемником стал Илия Аравийский (494-518), ученик св. Евфимия, вместе с Мартирием и Саввой постившийся с учителем в пустыне (Суг. V. Euth. 48; V. Sab. 10-11) [Шелудченко, 2019].

На 63-м году жизни Саввы в монастырь были приняты братья-строители Феодул и Геласий, благодаря которым в Великой лавре были возведены хлебня, больница, огромный храм прсв. Богородицы, паперть и другие постройки. Это произошло в 9 индикт (501 г.) (Cyr. V. Sab. 32; Marc. Com. a. 501; Pasch. Chr. a. 501). В Великую лавру доставлялись строительные материалы из Иерихона, а провизия - из Мадабы (Медвы) (Cyr. V. Sab. 26, 45-46). Внуком одного из помогавших лавре мирян из Мадабы Геронтия, а также сыном Фомы, был Геронтий, впоследствии являвшийся настоятелем киновии св. Евфимия во времена Кирилла. Он стал информатором автора по различным чудесам святого (Cуr. V. Sab. 46). Авва Геронтий был игуменом киновии еще в конце VI в., когда ее посещал Иоанн Mocx (Mosch. Prat. spir. 21). В Великой лавре при Кирилле было построено и украшено два водохранилища, верхнее и нижнее, под башней Саввы (Cyr. V. Sab. 82).

Через несколько лет у Саввы произошел новый конфликт с монахами, и он удалился в Скифопольскую пустыню. Там он жил при реке Гадарон в пещере, к святому стека- 
лись скифополитане и гадаринцы, так что Савва покинул эти места. Впоследствии около пещеры исавром Евматием была основана киновия, игуменом которой он стал, а его преемником - исавр Тарасий (Cyr. V. Sab. 33-34). Согласно «Житию св. Иоанна Молчальника», это произошло в 11 индикт, когда Иоанну Молчальнику шел 50-й год жизни (503 г.) (Cyr. V. Ioan. 9; Marc. Com. a. 503; Pasch. Chr. a. 503).

Когда Савва вернулся в Великую лавру, число его противников увеличилось до 60, и он снова ушел, на этот раз к Никополю, где основал киновию (Cyr. V. Sab. 34). Монахи Великой лавры просили у Саллюстия себе нового игумена, распространяя слухи, что св. Савва растерзан зверями в пустыне, однако патриарх, хорошо знавший Савву, им не поверил. Когда святой пришел в Иерусалим с новой братией, то патриарх Илия очень обрадовался и уговорил его вернуться к своей пастве в Великую лавру и изгнать непослушных монахов, написав соответствующее послание братии (Cyr. V. Sab. 34-35). Савва, вернувшись в Великую лавру, в Никопольской киновии оставил преемником ученика Севериана, возможно, того, который впоследствии основал лавру Перикарпарвариха (Cyr. V. Sab. 16, 35) Преемником Севериана стал Домн, а после его смерти - Саварион, которого уже пожилого знал Кирилл Скифопольский в 540-550-е гг.

Противники Саввы, получив послание патриарха Илии, удалились из монастыря, разрушив перед этим башню святого, а также захватив много вещей. Им не удалось поступить в лавру Сукка, управляемую св. игуменом Акилином, и они удалились к Фекойскому потоку, заняв заброшенный монастырь еретиков (Cyr. V. Sab. 36). Это, видимо, был монастырь, основанный в Фекоях монофизитом Романом, учеником Эльпидия и сотоварищем Маркиана, который во времена императора Зенона (474-491) сошел с ума и был изгнан из своего монастыря, окончив дни без причастия в скитаниях по пустыне (Cyr. V. Euth. 46, 71). Отделившиеся монахи также могли быть монофизитами. Они терпели лишения, у них не было припасов, царило безначалие и анархия, и они находились в бедственном положении. Св. Савва решил им помочь и обратился к патриарху, который выделил 1 литру золота для этой цели, а также полномочия управлять монастырем. После этого Савва прибыл с мастерами и обустроил монастырь в течение 5 месяцев, назвав его Новая лавра, построив трапезную и церковь, освященную в 69-й год жизни св. Саввы (507 г.). Игуменом Новой лавры был назначен один из первых учеников св. Саввы Иоанн, пророк и чудотворец. Он скончался через 8 лет (в 515 г.), предсказав перед смертью, что в Новой лавре распространится ересь оригенизма, что сбылось во времена Кирилла (Cyr. V. Sab. 16, 36, 83-90). Его преемником стал римлянин Павел, продержавшийся в лавре полгода, после чего ушел в Аравию, в монастырь Капарвариху Севериана, где и скончался (Cyr. V. Sab. 36). В качестве его преемника Савва поставил своего ученика Агапита, с которым 25 лет назад ходил в паломничество, Савве на этот момент было уже 77 лет. Агапит боролся с ересью и изгнал из монастыря 4-х монахов-оригенистов во главе с Нонном, имевшим сильное влияние среди монахов. В результате среди монахов возникло недовольство игуменом, и они его изгнали. Агапит 5 лет управлял Новой лаврой, а после его смерти игуменом стал Мам, тайно принявший Нонна и его последователей обратно (520 г.) (Cyr. V. Sab. 36).

После обустройства Новой лавры Савва вместе с учеником Павлом ушел поститься к потоку в 15 стадиях к западу от Кастеллия, в 30 стадиях от Великой лавры. Там обнаружена пещера в Северном утесе. Взяв строителей Феодула и Геласия, Павла и других монахов, Савва превратил пещеру в церковь и основал там Пещерную киновию (Cyr. V. Sab. 37; V. Ioan. 9). В это же время Савва вернул из пустыни в Великую лавру Иоанна Молчальника, проведшего 6 лет в отшельничестве, это было во 2 индикт (Cyr. V. Ioan. 11, 14; Marc. Com. a. 509), так что время основания Пещерной киновии относится к 509 г., когда Савве было 70 лет. Настоятелем был поставлен Павел, и из Великой лавры ему в помощь выделены монахи Георгий, Кирик и Евстафий. Георгий был рукоположен в епископа Пелусийского, а Кирик и Евстафий последовательно стали преемниками Павла, после чего игуменом стал Сергий, вероятно, бывший в этом качестве во времена Кирилла. Лавре помогал пресвитер храма Воскресения и игумен Сионского монастыря Маркиан. Его стар- 
ший сын Антоний затем был рукоположен патриархом Илией в епископа Аскалонского, а младший Иоанн сделан диаконом храма Воскресения. Впоследствии он стал Иерусалимским патриархом после Илии (Cyr. V. Sab. 37, 56, 64).

Также приблизительно в это время Савва основал киновию Схолариев на месте башни императрицы Евдокии, обратив в истинную веру населявших его несторианских монахов. Ее настоятелем был поставлен его образованный ученик Иоанн, обратившийся в монашество, будучи в первом отряде схолариев при дворе в Константинополе (Cyr. V. Euth. 45; V. Sab. 38). В конце VI в. обитель посещал Иоанн Мосх (Mosch. Prat. spir. 178).

Другой его ученик Иаков пытался основать лавру у озера Семиустного в 15 стадиях от Великой лавры без разрешения святого, но Савва это не одобрил, Иаков тяжело заболел, а постройки были разрушены по приказу патриарха Илии. В итоге Савва основал Семиустную лавру в 5 стадиях к северу от первоначально планируемого места, выкупив землю там. Настоятелями были поставлены братья-греки Павел и Андрей (Cyr. V. Sab. 39).

Еще один монастырь был основан монахами-братьями Занном и Вениамином, поступившими в монастырь из Хеврона. Они попросили себе келью св. Саввы в 15 стадиях (на юго-запад?) от Великой лавры, где основали киновию, получившую название киновия Занна. Савва доставлял им все необходимое (Cyr. V. Sab. 42).

Помимо основания монастырей св. Савва активно участвовал в религиозной жизни Палестины, в частности в борьбе с ересями. На 73-м году жизни он был послан к императору Анастасию патриархом Илией, чтобы добиться мира в Иерусалимской церкви, так как император, симпатизировавший монофизитам, гневался на прохалкидонскую позицию Иерусалимского патриарха Илии, Антиохийского патриарха Флавиана и поддержку ими низложенного Константинопольского патриарха Македония и готовил Сидонский собор восточных иерархов для их низложения (Cyr. V. Sab. 50). Савва прибыл в Константинополь в 511 г., 13 лет спустя после отмены известного налога хрисаргира (Cyr. V. Sab. 54; Josh. Styl. 31) [Пигулевская, 2000]. Савва защитил патриарха Илию и произвел настолько сильное впечатление на императора, что тот выдал ему 1000 литр золота на развитие его монастырей, а также обещал отменить налог в 100 литр золота, наложенный на жителей Палестины (Cyr. V. Sab. 51-55), поручив это префекту претория Зотику [Martindale, 1980, p. 1206-1207] - начальнику, земляку и покровителю чиновника и писателя Иоанна Лида в 511 г. (Lyd. De mag. III.26) [Bandy, 2013]. Савва перезимовал в Константинополе, навестив императрицу Ариадну, а также родственниц императорского дома - Аникию Юлиану [Martindale, 1980, p. 635-636] и Анастасию, жену племянника императора Анастасия - Помпея, впоследствии принявшую монашество в Палестине. Покинул столицу Савва в 5 индикт (512 г.) (Cyr. V. Sab. 53-54; Marc. Com. a. 512).

Хотя Сидонский собор провалился, императору удалось сместить с антиохийского престола патриарха Флавиана, поставив на его место монофизита Севера (512-518). Патриарх Илия отказался от общения с ним. Когда Север послал свое вероисповедание Илии с войсками, св. Савва встал во главе монахов и изгнал их из Иерусалима. Так что в город был послан начальник Палестины Олимпий (Cyr. V. Sab. 56; Marc. Com. a. 513), скорее всего, консуляр Палестины (Not. Dign. Orient. I) [Seek, 1876]. В результате патриарх Илия был свергнут и сослан в Аил, а на его место поставлен Иоанн (516-524), сын Маркиана, младший брат Антония (Cyr. V. Sab. 37, 56, 64; Mosch. Prat. spir. 35). Его принуждали принять в общение Севера Антиохийского, но он, опираясь на поддержку св. Саввы, св. Феодосия Киновиарха и монахов, сделал всенародное исповедание веры против монофизитов в присутствии Ипатия, племянника императора, прибывшего в Иерусалим помолиться. Он выдал Феодосию и Савве по 100 литр золота на монастыри и такую же сумму - главным иерусалимским храмам (Cyr. V. Sab. 56). Император хотел арестовать и патриарха, и Савву с Феодосием, но из-за восстания Виталиана отложил свое решение. А св. Савва и Феодосий от имени всех монахов составили послание, где изложили свое вероисповедание и подтвердили готовность идти на смерть за веру, прося оставить Иерусалимскую Церковь в покое (Cyr. V. Sab. 57). 
После свержения патриарха Илии в Палестине началась засуха, длившаяся 5 лет, с 513 по 518 гг., в результате чего в регионе появилась саранча и случился мор, хотя монастыри св. Саввы страдали меньше других по его молитвам (Cyr. V. Sab. 58-59, 66-67).

На 80-й год жизни, в 9 индикт (518 г.), св. Савва посещал ссыльного патриарха Илию в Аиле вместе с игуменом киновии св. Евфимия Стефаном и игуменом иерихонских монастырей патриарха Илии Евлалием. В ночь на 10 июля патриарх сообщил о смерти императора Анастасия, предсказав свою собственную смерть через 10 дней, что и произошло. Об императоре сообщается, что его убил удар молнии во время грозы, когда он был практически один во дворце (Cyr. V. Sab. 60). Сообщения о смерти императора Анастасия от удара молнии или от страха перед ней есть во многих других источниках (Malal. XVI.22; Vict. Tun. Chron. a. 518; Pasch. Chr. a. 518; Mosch. Prat. spir. 38) [Dindorf, 1831; Болгов, 2014; Mommsen, 1894].

После восшествия на престол императора Юстина в 518 г. по всем провинциям было разослано постановление о вероисповедании Халкидонского собора. Патриарх Иоанн отправил св. Савву в Кесарию и Скифополь огласить постановление. В Кесарии его принимал св. Иоанн Хозевит, являвшийся тогда епископом города, который еще будучи отшельником, имел дело с монахами обителей св. Саввы (Cyr. V. Sab. 44, 61; Mosch. Prat. spir. 25; Evagr. HE. IV.7) [Кривушин, Кривушина, 1999-2003]. В Скифополе св. Савву встречал весь город во главе с митрополитом Феодосием в главном храме св. апостола Фомы. В Скифополе Савва совершил множество чудес, посетил монастырь Енфенаниф и св. отшельника Иоанна, а также посетил дом отца Кирилла Скифопольского Иоанна управителя епископского дома и помощника митрополита, который безмерно восхищался святым (Cyr. V. Sab. 61-63; 75).

Через 6 лет, когда старцу исполнилось 86 лет (524 г.), умер патриарх Иоанн, официально правивший 7 лет и 9 месяцев, то есть с 516 г. Его преемником на престоле стал патриарх Петр, который оказывал большую честь Савве, часто посещая его в пустыне, в том числе и за то, что святой исцелил его сестру (Cyr. V. Sab. 68).

Вскоре после этого произошла смерть благочестивой патрикии Аникии Юлианы, которую датируют 528 г. [Capizzi, 1968], то есть когда святому было 90 лет. Она завещала огромную сумму денег в Иерусалим, в том числе в монастыри св. Саввы, которого весьма почитала после достопамятной встречи. Деньги доставили евнухи и тоже просили принять их в лавру, но Савва отослал их в киновию Феодосия. Освоив монашескую жизнь, они попросили у патриарха Петра выделить им монастырь для поселения - тот отослал их в иерихонские монастыри св. патриарха Илии. За деньги они добились от тогдашнего игумена Александра выделения им особого монастыря, названного Евнушеским (Cyr. V. Sab. 69). Его посещал Иоанн Mocx (Mosch. Prat. spir. 135-136, 138) в конце VI в.

На 91-м году жизни Саввы (529 г.) скончался его друг и сподвижник св. Феодосий Киновиарх. Через 4 месяца в регионе разразилось восстание самаритян. Оно началось в 7 индикт и продолжалось в течение 529-530 гг. Столицей самаритян был Неаполь (совр. Наблус), а вождем - некто Юлиан. Самаритяне пытали и убивали христиан, уничтожая целые поселения и сжигая христианские церкви. Особо неистовствовали они около Никополя. Также сильно пострадали многие места в Скифополе. Обозленные местные жители заживо сожгли имперского чиновника и самаритянина Сильвана по пророчеству святого. Император разгневался и послал против самаритян войска. Восстание было подавлено, а большая часть мятежников истреблена - погибло больше 20 тысяч самаритян (Cyr. V. Sab. 61, 70; Malal. XVIII.35; Marc. Com. a. 529; Pasch. Chr. a 530).

После подавления восстания св. Савва во второй раз отправился в качестве посла в Константинополь, на этот раз по поручению патриарха Петра, дабы облегчить налоги разоренной Палестине. Юстиниан принял святого с необычайным почетом, выслав корабли и епископов ему навстречу. Император увидел над его головой нимб и почтил его высокой честью, прося помолиться о деторождении императрицы Феодоры, но святой не стал этого делать, видя монофизитские взгляды императрицы. Савва просил о шести вещах: об облег- 
чении податей для разоренного региона, восстановлении сожженных храмов, строительстве церкви прсв. Богородицы и больницы в Иерусалиме, постройке крепостей от набегов сарацин рядом со своими монастырями, и, наконец, об искоренении арианской, несторианской и оригеновой ереси, обещая, что за это Бог вознаградит императора возвратом Запада. Император Юстиниан (527-565) все исполнил в точности, выделив на восстановление региона 30 кентиариев золота, положив 3700 золотых на годовое содержание больницы, а также 1000 монет и стражу для монастырей св. Саввы (Cyr. V. Sab. 70-74). Против самаритян были изданы репрессивные законы, запрещавшие им занятие должностей, наследование, отправление культов, предписывая разрушить их синагоги (Cyr. V. Sab. 71; CJ I.5.13-22) [Krueger, 1877]. Савва отплыл из Константинополя в 9 индикт (531 г.), после чего полученные деньги распределил между монастырями (Cyr. V. Sab. 74; Marc. Com. a. 531).

Находившийся с ним в посольстве ученик Иеремия по каким-то причинам остался недоволен распределением денег и выселился из Великой лавры, решив основать собственную обитель в 5 стадиях к северу от Пещерного монастыря. Савва весьма обрадовался и выделил много денег и материалов на монастырь Иеремии (Cyr. V. Sab. 74). Представляется, что это была лавра.

После возвращения в Иерусалим Савву вновь послали в Кесарию и Скифополь, дабы обнародовать имперские указы. В Скифополе его снова встречал весь город, и в это время состоялась достопамятная встреча 92-летнего старца и маленького 7-летнего мальчика Кирилла (будущий монах-агиограф), которого святой нарек своим учеником и «сыном пустынных отцов», благословил и поручил следить за ним и его образованием митрополиту Феодосию (Cyr. V. Sab. 75).

Вернувшись в Иерусалим, Савва предвидел свою кончину. Он скончался в ходе непродолжительной болезни на следующий год, в декабре 10 индикта (532 г.) (524 по александрийской эре и 6024 от Сотворения мира), в возрасте 93 лет, на 6-й год царствования императора Юстиниана, во 2 год после консульства Лампадия и Ореста (Cyr. V. Sab. 75-76; V. Ioan. 16; Marc. Com. a. 532; Pasch. Chr. a. 532). О чудесах при его кончине Кириллу рассказал диакон и художник в Иерусалиме Ромул, а его нетленные мощи, положенные в Великой лавре, видел сам Кирилл за год до времени написания работы, то есть в 556 или 557 г. (Cyr. V. Sab. 77-78).

После кончины святого появились свидетельства о многих его посмертных чудесах (Cyr. V. Sab. 79-82), что находит параллели в «Житии св. Евфимия» [Elliott-Binns, 1989, p. 67-68] и является признаком житийного жанра [Маторина, 2011]. Его преемником в Великой лавре стал Мелит, игуменствовавший 5 лет, после чего в 15 индикт (537 г.) настоятелем стал Геласий, строитель и брат Феодула (Cyr. V. Sab. 84; Marc. Com. a. 537; Pasch. Chr. a. 537).

В это время в Палестине развернулась борьба между монахами-халкидонитами и последователями Оригена (впоследствии оригенисты распались на два направления: протоктистов/тетрадитов и исохристов) в Великой и Новой лавре на протяжении 530-540-х гг. (Cуr. V. Sab. 83-90). Вплоть до 553 г. оригенисты держали верх в Палестинской пустыне, несмотря на эдикт императора Юстиниана против оригенизма 543 г. [Elliott-Binns, 1989, p. 49]. Их поддерживал сам патриарх Петр, обвиняя монахов Великой лавры в том, что они стали еретиками-савваитами, то есть поклонялись св. Савве как божеству. Оплотом оригенистов стала Новая лавра, в которой игуменом был Феодор Аскрида, ставший впоследствии епископом Кесарии Кападокийской, а также идейный вдохновитель оригенизма Нонн.

Великой лаврой Геласий руководил 9 лет и умер в 9 индикт (546 г.), возвращаясь из Константинополя (Cyr. V. Sab. 87; Marc. Com. a. 546; Pasch. Chr. a. 546). Его преемником стал оригенист Георгий, которого выгнали свои же монахи через 7 месяцев за непотребства. В это время св. Иоанн Молчальник, являвшийся идейным вдохновителем антиоригенистской борьбы, с монахами-халкидонитами ушел из лавры (Cyr. V. Sab. 84, 88, 90; V. Ioan. 16). После Георгия игуменом Великой лавры стал авва Кассиан Скифопольский, который умер через 10 месяцев, в 16-й год по смерти св. Саввы (547 г.). Вероятно, именно в положении его мощей в Великой лавре участвовал Кирилл (Cyr. V. Sab. 78, 88). Его преемником стал авва Конон 
Киликийский. Возможно, это тот самый Конон Киликиец, который подвизался в киновии св. Феодосия и прославился добродетельной жизнью (Mosch. Prat. spir. 22). В 23-й год по смерти Савы, через 8 месяцев после V Вселенского собора (554 г.), оригенистов изгнали из Новой лавры, населив ее 120 монахами Великой лавры и 60 - из других монастырей, в том числе взяв Кирилла Скифопольского из монастыря св. Евфимия [Elliott-Binns, 1989, p. 50].

Таким образом, «Житие св. Саввы» Кирилла Скифопольского сочетает в себе жанр агиографии и церковной истории, выгодно отличаясь от другой агиографической литературы в пользу историчности. В основу повествования автор положил аутентичные устные источники о жизни святого: свидетельства его сподвижников, учеников и современников, а также личные наблюдения и воспоминания. Все события строго датированы по нескольким хронологическим привязкам, которые подтверждаются в других источниках, позволяя точно восстановить канву исторических событий. Св. Савва прожил долгую жизнь и сыграл огромную роль в развитии палестинского монашества, населив всю Иудейскую пустыню благодаря основанию и развитию многочисленных лавр и киновий, оставив после себя множество учеников. Он являлся значимой фигурой и активным участником религиозной жизни региона, непримиримо борясь с антихалкидонскими ересями и встав во главе монахов-халкидонитов.

\section{Список сокращений:}

CJ - Codex Justinianus

Cyr. V. Cyriac. - Cyrillus Scythopolitanus, Vita Cyriaci

Cyr. V. Euth. - Cyrillus Scythopolitanus, Vita Euthymii

Cyr. V. Ioan. - Cyrillus Scythopolitanus, Vita Ioannis

Cyr. V. Sab. - Cyrillus Scythopolitanus, Vita Sabbae

Evagr. HE. - Evagrius, Historia Ecclesiastica

Josh. Styl. - Joshua the Stylite, Chronicon

Lyd. De mag. - Ioannes Lydus, De Magistratibus

Malal. - Ioannes Malalas, Chronographia

Marc. Com. - Marcellinus Comes, Chronicon

Mosch. Prat. spir. - Ioannes Moschus, Pratum spirituale

Not. Dign. Orient. - Notitia Dignitatum in partibus Orientis

Pasch. Chr. - Chronicon Paschale

V. Geras. - Anonymus, Vita Gerasimi

Vict. Tun. Chron. - Victor Tununensis, Chronicon Continuans Ubi Prosper Desinit

\section{Приложение}

Монастыри, основанные св. Саввой:

1) Великая лавра (около горы (башни) Евдокии, на юго-восток, в 35 стадиях к востоку от киновии св. Феодосия Киновиарха).

2) Новая лавра (около Фекойского потока).

3) Семиустная лавра (в 5 стадиях к северу от Семиустного озера, которое в 15 стадиях от Великой лавры).

4) Подготовительная киновия Великой лавры (рядом с Великой лаврой).

5) Кастеллийская киновия (в 15 стадиях к северо-востоку от Великой лавры).

6) Никопольская киновия.

7) Пещерная киновия (в 15 стадиях к западу от Кастеллийской киновии, в 30 стадиях от Великой лавры на северо-восток, Кастелий - с востока, монастырь Схолариев - в 5 стадиях с запада).

8) киновия Схолариев (на горе (башне) Евдокии, в 30 стадиях к югу от монастыря св. Евфимия).

Монастыри, основанные учениками св. Саввы:

Фирмин - лавра в Мамхасе.

Севериан - лавра Перикарпарвариха (около Карпарварихи).

Юлиан Кирт - лавра Неслкерава у Иордана.

Евматий - киновия Евматия (около Скифополя и Гадары).

Занн и Вениамин - киновия Занна (15 стадий к Ливии от Великой лавры).

Иеремия - монастырь Иеремии (5 стадий к северу от Пещерной киновии). 


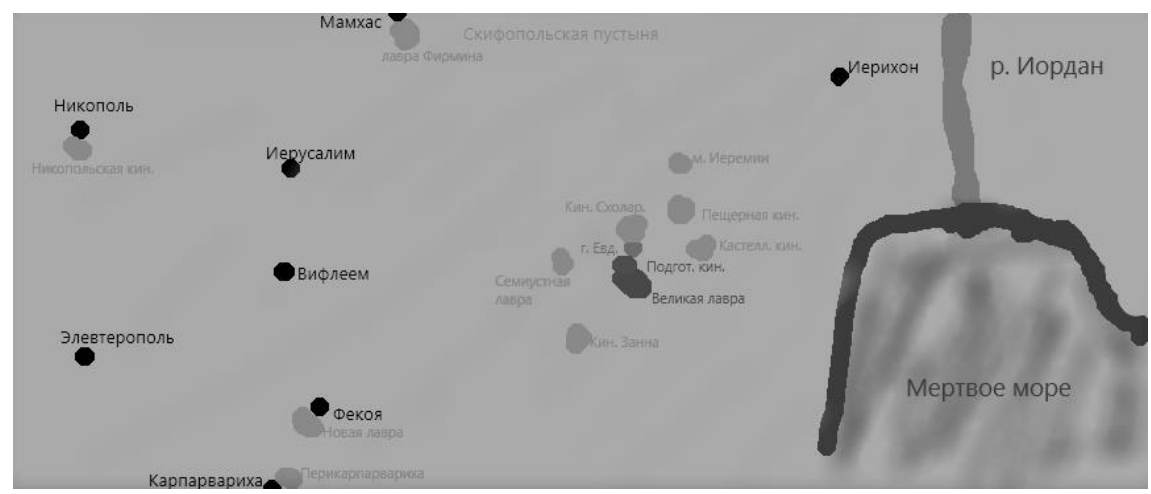

Рис. 1. Карта расположения монастырей св. Саввы и его учеников (по «Житию св. Саввы») Fig. 1. Map of the location of the monasteries of St. Saba and his disciples (according to «The Life of St. Saba»)

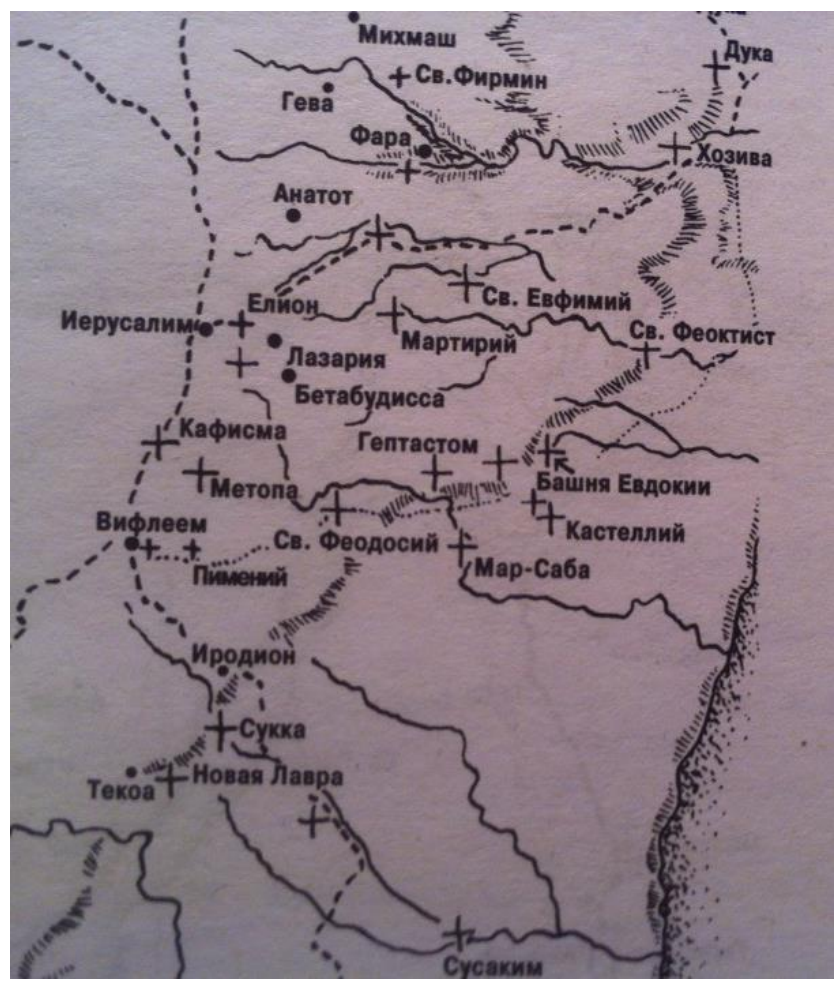

Рис. 2. Карта расположения основных монастырей в Иудейской пустыне

[Читти, 2007, с. 96-97, карта 2]

Fig. 2. Map of the location of the main monasteries in the Judean desert [Chitti, 2007, p. 96-97, map 2]

\section{Список литературы}

1. Болгов Н.Н. (изд.). 2010. Марцеллин Комит. Хроника. Белгород, НИУ «БелГУ», 210.

2. Болгов Н.Н. (изд.). 2014. Иоанн Малала. Хронография. Книги XIII-XVIII. Мир поздней античности. Документы и материалы. Выпуск 2. Белгород, НИУ «БелГУ», 180.

3. Кривушин И.В., Кривушина Е.С. (изд.). 1999-2003. Евагрий Схоластик. Церковная история в 6 кн. В 3 т. СПб., Алетейя, 672.

4. Кузенков П.В. 2014. Христианские хронологические системы. История летоисчисления в святоотеческой и восточнохристианской традиции III-XV веков. М., Русский издательский центр имени святого Василия Великого, 815.

5. Маторина У.М. 2011. Жанрово-композиционное своеобразие византийского преподобнического жития Саввы Освященного). Современная филология: материалы междунар. заоч. науч. конф. (г. Уфа, апрель 2011 г.). Под общ. ред. Г.Д. Ахметовой. Уфа, Лето: 49-55.

6. Пигулевская Н.В. (изд.). 2000. Хроника Иешу Стилита. Сирийская средневековая историография. Исследования и переводы. СПб., Дмитрий Буланин: 571-620. 
7. Помяловский И. (изд.). 1885. Кирилл Скифопольский. Житие св. Саввы Освященного, составленное св. Кириллом Скифопольским в древнерусском переводе. Палестинский патерик. Вып.1. СПб., Типография В. Киршбаума, 155.

8. Помяловский И. (изд.). 1893. Кирилл Скифопольский. Житие иже во Святых отца нашего Иоанна, Епископа и Молчальника. Палестинский патерик. Вып. 3. СПб., Типография В. Киршбаума, 29.

9. Помяловский И. (изд.). 1895а. Житие и подвиги иже во святых отца нашего и богоносца Герасима Иорданского. Палестинский патерик. Вып. 6. СПб., Типография В. Киршбаума, 14.

10. Помяловский И. (изд.). 1895b. Кирилл Скифопольский. Житие Преподобного Кириака Отшельника. Палестинский патерик. Вып. 7. СПб., Типография В. Киршбаума, 23.

11. Помяловский И. (изд.). 1898. Кирилл Скифопольский. Житие иже во Святых отца нашего Евфимия Великого. Палестинский патерик. Вып. 2. СПб., Типография В. Киршбаума, 108.

12. Помяловский И. (изд.). 1899. Кирилл Скифопольский. Житие иже во Святых отца нашего Аввы Феодосия Киновиарха. Палестинский патерик. Вып. 8. СПб., Типография В. Киршбаума, 94.

13. Ткачев Е.В. 2014. Кирилл Скифопольский. Православная энциклопедия. Т. 34: 614-622.

14. Хитров М.И. (протоиер.) (изд.). 1915. Луг духовный. Творение блаженного Иоанна Мосха. Сергиев Посад, Тип. Св.-Тр. Сергиевой лавры, 360.

15. Читти Д. 2007. Град Пустыня. Введение в изучение египетского и палестинского монашества в христианской империи. СПб., Библиополис, 320.

16. Шелудченко Ю.В. 2019. «Житие св. Евфимия» Кирилла Скифопольского в монашеской традиции и его историческая основа. Кондаковские чтения VI. Античность - Византия Древняя Русь. Материалы VI международной научной конференции. Белгород, БелГУ: 190-214.

17. Bandy A. (eds.). 2013. Ioannes Lydus. On the Powers or The Magistracies of the Roman State. Lewiston, New York, The Edwin Mellen Press, 319.

18. Binns J. (eds.). 1991. Lives of the Monks of Palestine by Cyril Scythopolis. Cistercian Publications, Kalamazoo, Michigan, 305.

19. Capizzi C. 1968 . Anicia Giuliana (462 ca. -530 ca.): Ricerche sulla sua famiglia e la sua vita. Rivista di studi bizantini e neoellenici. Vol. n.s. 5: 191-226.

20. Dindorf L. (eds.). 1831. Ioannis Malalae chronographia. Corpus Scriptorum Historiae Byzantinae. T. 32. Bonn, Impensis ed. Weberi, 799.

21. Dölger F., Schwartz E. 1940. Kyrillos von Skyhtopolis. Byzantinische Zeitschrift. 40: 47-484.

22. Elliott-Binns J. 1989. Cyril of Scythopolis and the Monasteries of the Palestinian Desert. A Dissertation for Degree of Doctor of Philosophy. King's College London, 287.

23. Honigmann E. 1950. Juvenal of Jerusalem. Dumbranton Oaks Paper. 5: 210-279.

24. Krueger P. (eds.). 1877. Codex Iustinianus. Berlin, 1102.

25. Martindale J.R. (eds.). 1980. The Prosopography of the Later Roman Empire. Vol. II, A. D. 395-527. Cambridge University Press, 1386.

26. Mommsen Th. (eds.). 1894. Victoris Tonnennensis episcopi chronica a. 444-567. Monumenta Germaniae Historica, AA. Bd. 11. Berlin, 163-184.

27. Schwartz E. (eds.). 1939. Kyrillos von Skythopolis. Leipzig, 415.

28. Seek O. (eds.). 1876. Notitia dignitatum; accedunt Notitia urbis Constantinopolitanae et laterculi prouinciarum. Berolini apud Weidmannos, 340.

29. Trapp E. 1992. Johannes Moschos. Biographisch-Bibliographisches Kirchenlexikon (BBKL). Band 3, Bautz, Herzberg: 491-492.

30. Whitby M., Whitby M. (eds.). 1989. Chronicon Paschale 284-628 A. D. Liverpool, Liverpool University Press, 242.

\section{References}

1. Bolgov N.N. (izd.) [ed.]. 2010. Marcellin Komit. Hronika. [Marcellin Komit. Chronicle]. Belgorod, NIU «BelGU», 210.

2. Bolgov N.N. (izd.) [ed.]. 2014. Ioann Malala. Hronografija. Knigi XIII-XVIII. Mir pozdnej antichnosti. Dokumenty i materialy. Vypusk 2. [John Malala. Chronography. Books XIII-XVIII. World of Late Antiquity. Documents and materials. Issue 2]. Belgorod: NIU «BelGU», 180.

3. Krivushin I.V., Krivushina E.S. (izd.) [ed.]. 1999-2003. Evagrij Sholastik. Cerkovnaja istorija v 6 kn. V 3 t. [Evagrius Scholastic. Church History in 6 books. In 3 t.]. SPb., Aletejja, 672. 
4. Kuzenkov P.V. 2014. Hristianskie hronologicheskie sistemy. Istorija letoischislenija v svjatootecheskoj i vostochnohristianskoj tradicii III-XV vekov. [Christian chronological systems. History of chronology in the patristic and eastern Christian tradition of the III-XV centuries]. M., Russkij izdatel'skij centr imeni svjatogo Vasilija Velikogo, 815.

5. Matorina U.M. 2011. Zhanrovo-kompozicionnoe svoeobrazie vizantijskogo prepodobnicheskogo zhitija Savvy Osvjashhennogo). Sovremennaja filologija: materialy mezhdunar. zaoch. nauch. konf. (g. Ufa, aprel' 2011 g.). Pod obshh. red. G.D. Ahmetovoj. [Genre-compositional originality of the Byzantine reverend life of Sava the Sanctified). Modern philology: international materials. extramural scientific conf. (Ufa, April 2011). Under the total. ed. G.D. Akhmetova]. Ufa: Leto, 49-55.

6. Pigulevskaja N.V. (izd.) [ed.]. 2000. Hronika Ieshu Stilita. Sirijskaja srednevekovaja istoriografija. Issledovanija i perevody. [Chronicle of Yeshu Style. Syrian medieval historiography. Research and translations]. SPb., Dmitrij Bulanin, 571-620.

7. Pomjalovskij I. (izd.) [ed.]. 1885. Kirill Skifopol'skij. Zhitie sv. Savy Osvjashhennogo, sostavlennoe sv. Kirillom Skifopol'skim v drevnerusskom perevode. Palestinskij paterik. Vyp.1 [Cyril of Scythopol. Life of St. Sava the Sanctified, composed by St. Cyril Skifopolsky in the old Russian translation. Palestinian Paterik. Issue 1]. SPb., Tipografija V. Kirshbauma, 155.

8. Pomjalovskij I. (izd.) [ed.]. 1893. Kirill Skifopol'skij. Zhitie izhe vo Svjatyh otca nashego Ioanna, Episkopa i Molchal'nika. Palestinskij paterik. Vyp. 3. [Cyril of Scythopol. The life of the same in the Saints of our father John, Bishop and Silent. Palestinian Paterik. Issue 3.]. SPb., Tipografija V. Kirshbauma, 29.

9. Pomjalovskij I. (izd.) [ed.]. 1895a. Zhitie i podvigi izhe vo svjatyh otca nashego i bogonosca Gerasima Iordanskogo. Palestinskij paterik. Vyp. 6 [The life and exploits of others in the saints of our father and God-bearer Gerasim of Jordan. Palestinian Paterik. Issue 6]. SPb., Tipografija V. Kirshbauma, 14.

10. Pomjalovskij I. (izd.) [ed.]. 1895b. Kirill Skifopol'skij. Zhitie Prepodobnogo Kiriaka Otshel'nika. Palestinskij paterik. Vyp. 7 [Cyril of Scythopol. The Life of Rev. Cyriac the Hermit. Palestinian Paterik. Issue 7]. SPb., Tipografija V. Kirshbauma, 23.

11. Pomjalovskij I. (izd.) [ed.]. 1898. Kirill Skifopol'skij. Zhitie izhe vo Svjatyh otca nashego Evfimija Velikogo. Palestinskij paterik. Vyp. 2 [Cyril of Scythopol. The life of those in the Saints of our father Euthymius the Great. Palestinian Paterik. Issue 2]. SPb., Tipografija V. Kirshbauma, 108.

12. Pomjalovskij I. (izd.) [ed.]. 1899. Kirill Skifopol'skij. Zhitie izhe vo Svjatyh otca nashego Avvy Feodosija Kinoviarha. Palestinskij paterik. Vyp. 8 [Cyril of Scythopol. The life of the same in the Saints of our father Abba Theodosius Kinoviarch. Palestinian Paterik. Issue 8]. SPb., Tipografija V. Kirshbauma, 94.

13. Tkachev E.V. 2014. Kirill Skifopol'skij. Pravoslavnaja jenciklopedija [Cyril of Scythopol]. [Orthodox Encyclopedia]. T. 34: 614-622.

14. Hitrov M.I. (protoier.) [archpriest] (izd.) [ed.]. 1915. Lug duhovnyj. Tvorenie blazhennogo Ioanna Mosha. [The spiritual meadow. Creation of Blessed John Mosch]. Sergiev Posad, Tip. Sv.-Tr. Sergievoj lavry, 360.

15. Chitti D. 2007. Grad Pustynja. Vvedenie v izuchenie egipetskogo i palestinskogo monashestva v hristianskoj imperii. [Desert City. An introduction to the study of Egyptian and Palestinian monasticism in the Christian empire]. SPb., Bibliopolis, 320.

16. Sheludchenko Ju.V. 2019. «Zhitie sv. Evfimija» Kirilla Skifopol'skogo v monasheskoj tradicii i ego istoricheskaja osnova. Kondakovskie chtenija VI. Antichnost' - Vizantija - Drevnjaja Rus'. Materialy VI mezhdunarodnoj nauchnoj konferencii. [«The Life of St. Euphemia» by Cyril of Scythopolis in the monastic tradition and its historical basis. Kondakov Readings VI. Antiquity - Byzantium - Ancient Russia. Materials of the VI international scientific conference]. Belgorod, BelGU: 190-214.

17. Bandy A. (eds.). 2013. Ioannes Lydus. On the Powers or The Magistracies of the Roman State. Lewiston, New York, The Edwin Mellen Press, 319.

18. Binns J. (eds.). 1991. Lives of the Monks of Palestine by Cyril Scythopolis. Cistercian Publications, Kalamazoo, Michigan, 305.

19. Capizzi C. 1968 . Anicia Giuliana (462 ca. -530 ca.): Ricerche sulla sua famiglia e la sua vita. Rivista di studi bizantini e neoellenici. Vol. n.s. 5: 191-226.

20. Dindorf L. (eds.). 1831. Ioannis Malalae chronographia. Corpus Scriptorum Historiae Byzantinae. T. 32. Bonn, Impensis ed. Weberi, 799.

21. Dölger F., Schwartz E. 1940. Kyrillos von Skyhtopolis. Byzantinische Zeitschrift. 40: 47-484. 
22. Elliott-Binns J. 1989. Cyril of Scythopolis and the Monasteries of the Palestinian Desert. A Dissertation for Degree of Doctor of Philosophy. King's College London, 287.

23. Honigmann E. 1950. Juvenal of Jerusalem. Dumbranton Oaks Paper. 5: 210-279.

24. Krueger P. (eds.). 1877. Codex Iustinianus. Berlin, 1102.

25. Martindale J.R. (eds.). 1980. The Prosopography of the Later Roman Empire. Vol. II, A. D. 395-527. Cambridge University Press, 1386.

26. Mommsen Th. (eds.). 1894. Victoris Tonnennensis episcopi chronica a. 444-567. Monumenta Germaniae Historica, AA. Bd. 11. Berlin, 163-184.

27. Schwartz E. (eds.). 1939. Kyrillos von Skythopolis. Leipzig, 415.

28. Seek O. (eds.). 1876. Notitia dignitatum; accedunt Notitia urbis Constantinopolitanae et laterculi prouinciarum. Berolini apud Weidmannos, 340.

29. Trapp E. 1992. Johannes Moschos. Biographisch-Bibliographisches Kirchenlexikon (BBKL). Band 3, Bautz, Herzberg: 491-492.

30. Whitby M., Whitby M. (eds.). 1989. Chronicon Paschale 284-628 A. D. Liverpool, Liverpool University Press, 242.

\section{Ссылка для цитирования статьи Link for article citation}

Шелудченко Ю.В. 2020. Савва Освященный (439-532 гг.) и монастыри иудейской пустыни в изображении Кирилла Скифопольского. Via in tempore. История. Политология, 47(1): 54-66.

DOI 10.18413/2687-0967-2020-47-1-54-66

Sheludchenko Yu.V. 2020. St. Sabbas the Sanctified (439-532) and monasteries of the jewish desert in the depiction of Cyril of Skythopolis. Via in tempore. History and political science, 47(1): 54-66 (in Russian). DOI 10.18413/2687-0967-2020-47-1-54-66 